\title{
Virus-like particles associated with Lyngbya majuscula (Cyanophyta; Oscillatoriacea) bloom decline in Moreton Bay, Australia
}

\author{
Ian Hewson $^{1, *}$, Judith M. O'Neil ${ }^{2}$, William C. Dennison ${ }^{1}$ \\ ${ }^{1}$ Marine Botany Group, Department of Botany and \\ ${ }^{2}$ Centre for Marine Studies, University of Queensland, Brisbane, Queensland 4072, Australia
}

\begin{abstract}
Expansive blooms of the toxic cyanobacterium Lyngbya majuscula were observed in 2 shallow water regions of Moreton Bay, Australia. The rapid bloom decline ( 8 to $<1 \mathrm{~km}^{2}$ in $<7 \mathrm{~d}$ ) prompted an investigation of the role of cyanophage viruses in the ecophysiology of $L$. majuscula. Virus-like particles produced by decaying L. majuscula were observed using electron microscopy. The virus-like particles were similar in morphology to viruses in the genus Cyanostyloviridae. The effect of viruses on $L$. majuscula photosynthesis was investigated by: (1) creating a virus concentrate using tangential-flow ultrafiltration of seawater surrounding L. majuscula; (2) inoculating L. majuscula with the concentrate; and (3) measuring photosynthetic response using a pulse-amplitude modulated fluorometer. Virus concentrate addition resulted in decreased initial fluorescence, decreased photochemical efficiency and decreased electron transport rate in rapid light curves after $5 \mathrm{~d}$. Viruses present within L. majuscula filaments may play an important role in the bloom dynamics of this ecologically important cyanobacterium.
\end{abstract}

KEY WORDS: Lyngbya majuscula $\cdot$ Cyanophage $\cdot$ Virus $\cdot$ Lysogeny

Resale or republication not permitted without written consent of the publisher

\section{INTRODUCTION}

Marine viruses are now recognised as being both ubiquitous and abundant in aquatic environments (Proctor et al. 1988, Bergh et al. 1989). The typical surface water abundance of virus-like particles (VLP), which are viruses that have not been cultured to determine host specificity, is $10^{10} \mathrm{VLP} \mathrm{l}^{-1}$ (Fuhrman 1999). Substantial portions of marine virus communities are viruses specific to unicellular cyanobacteria (cyanophage) in oceanic phytoplankton. Approximately $25 \%$ of all free VLP in the Gulf of Mexico are specific to Synechococcus spp. (Suttle \& Chan 1993). Few cyanophages specific to macroscopic, filamentous cyanobacteria have been identified (Ohki \& Fujita 1996, Ohki 1999). Only temperate cyanophages

${ }^{*}$ Present address: Department of Biological Sciences, University of Southern California, 3616 Trousdale Parkway, AHF 107, Los Angeles, California 90089-0371, USA.

E-mail: hewson@usc.edu that remain within the host genome until induced by environmental stimuli (Wilson \& Mann 1997) have been reported in marine non-heterocystous cyanobacteria. Ohki \& Fujita (1996) isolated a temperate cyanophage specific to the tropical cyanobacterium Phormidium persicinum, while Ohki (1999) isolated a temperate phage specific to Trichodesmium spp. The isolation of these cyanophages has caused review of the role of viruses in the demise of cyanobacterial blooms (Suttle 2000).

Large benthic mats of the filamentous cyanobacterium Lyngbya majuscula have recently formed during summer months in northern waters of Moreton Bay, Queensland, Australia $\left(27^{\circ} \mathrm{S}, 153^{\circ} \mathrm{E}\right.$; Fig. 1) (Dennison \& Abal 1999). L. majuscula produces a powerful suite of toxins including dermatitis-causing compounds and tumour promoters, and aerosolisation of dried $L$. majuscula has been linked with asthma-like symptoms in humans (Dennison et al. 1999). L. majuscula is characterised by wide cells (30 to $40 \mu \mathrm{m}$ wide and $5 \mu \mathrm{m}$ thick), a thick, gelatinous sheath and a distinct dark 


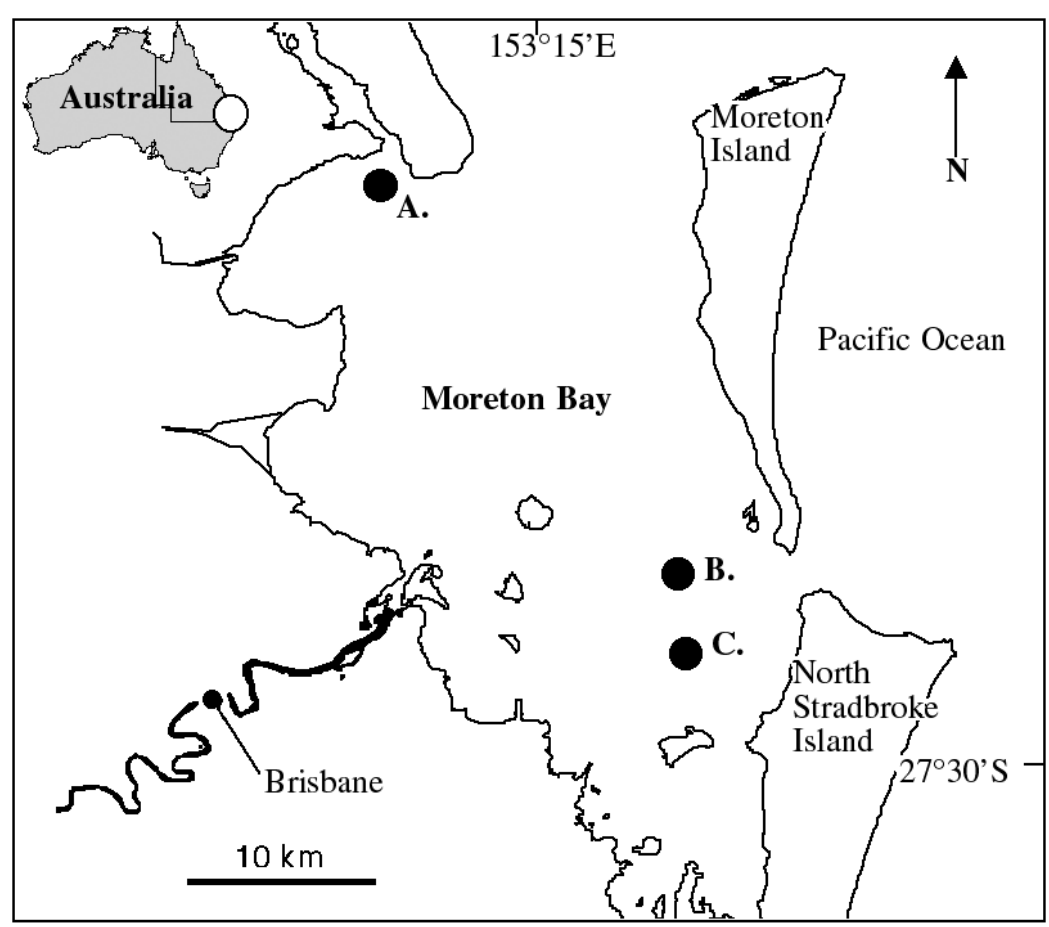

Fig. 1. Map of Moreton Bay, Australia, showing location of (A) Deception Bay bloom in austral summer 2000, (B) site of decomposing Lyngbya majuscula during Amity Banks bloom in austral spring 2000 and (C) site of healthy L. majuscula collection on Amity Banks

colouration (olive to green-grey; Fig. 2). L. majuscula is non-heterocystous; however, high nitrogen fixation rates have been recorded in association with L. majuscula (Dennison et al. 1999).

A large bloom of Lyngbya majuscula was observed in northern Deception Bay (a northern embayment that forms part of Moreton Bay) during late austral summer 2000. The bloom disintegrated rapidly $(<7 \mathrm{~d})$ after onset of decay symptoms, which included chlorosis, lack of photosynthesis and the colonisation by heterotrophic bacteria, e.g., Beggiatoa spp. A larger second bloom of L. majuscula formed later in mid-austral spring 2000 on Amity and Moreton Banks in eastern Moreton Bay. The second bloom did not collapse as rapidly as the first, but the cyanobacteria were observed to form extensive mats in deeper (2 to $3 \mathrm{~m}$ water depth) areas, which displayed similar symptoms to the decomposing cyanobacteria at Deception Bay. The second bloom eventually disappeared after 4 to $6 \mathrm{wk}$.

The rapid decline of the Deception Bay Lyngbya majuscula bloom suggests that cyanophages may play a role in the ecophysiology and bloom dynamics of $L$. majuscula. This study describes the observation of virus production from decaying $L$. majuscula and the effects of these viruses on the physiology of healthy cyanobacteria.

\section{MATERIALS AND METHODS}

Observation of viruses produced by decaying Lyngbya majuscula. L. majuscula was collected in plastic bags by SCUBA divers at the Deception Bay site (Fig. 1, point A; approximately $3 \mathrm{~m}$ water depth) at the first observation of bloom decline, and samples were transported at ambient temperature to the University of Queensland in 301 black polycarbonate drums containing seawater collected at the bloom site.

Viruses, bacteria and phytoplankton were removed from $100 \mathrm{ml}$ aliquots of Deception Bay seawater by filtration through Whatman (Maidstone, UK) $0.02 \mu \mathrm{m}$ Anodisc filters while filtrate was retained in sterile $90 \mathrm{~mm}$ plastic Petri dishes. Sections of Lyngbya majuscula were blotted dry on tissue paper and gently placed using forceps into the open end of a $5 \mathrm{ml}$ cut-off syringe. A volume of L. majuscula ( $\sim \mathrm{ml}$ measured in the syringe) was then placed into the $0.02 \mu \mathrm{m}$ filtered seawater $(50 \mathrm{ml})$. Care was taken to minimise time $(<20 \mathrm{~s})$ between blotting and submersion in virus-free seawater. Small pieces of Lyngbya majuscula were blotted dry, immersed in virus-free seawater and observed under epifluoresence microscopy to confirm the absence of associated bacteria and protists. Samples were prepared according to the protocols of Noble \& Fuhrman (1998). Briefly, a small volume of water (2 ml) containing L. majuscula filaments was filtered through a Whatman Anodisc $0.02 \mu \mathrm{m} \mathrm{Al}_{2} \mathrm{O}_{3}$ filter, dried on the surface of tissue paper and stained with 1:100000 diluted SYBR Green I (Molecular Probes Inc., Eugene, OR, USA). Filters were then dried once more before mounting on a glass slide using 50:50 phosphatebuffered saline and glycerol containing $0.1 \% \mathrm{w} / \mathrm{v} p$ phenylenediamine as a combined mountant and antifade solution. Slides were observed using epifluoresence microscopy at $1000 \times$ magnification under blue light excitation.

To determine whether temperate cyanophages inducible through UV light irradation were present in Lyngbya majuscula filaments, 3 replicates of cyanobacteria were subjected to UV light radiation for $60 \mathrm{~s}$ using an Oliphant UV lamp ( $\lambda \sim 250$ to $350 \mathrm{~nm}$ ) (Oliphant UV Products, Arndell Park, NSW, Australia). Petri dishes (including 3 replicates not subjected to UV light treatment) were placed on a shaker table for $4 \mathrm{~h}$ and incubated at a temperature of $\sim 25^{\circ} \mathrm{C}$ 
(approximate water temperature at the bloom site). After agitation, $L$. majuscula was removed from the Petri dishes, and the lysate was filtered through Whatman $0.7 \mu \mathrm{m} \mathrm{GF} / \mathrm{F}$ filters and subsequently through Durapore $0.22 \mu \mathrm{m}$ polycarbonate (low-binding properties) filters to remove single cellular debris. The filtered lysate was concentrated using Amicon Centriprep centrifugal ultrafilters (Millipore Corp., Bedford, MA, USA) following the manufacturer's recommendations. Approximately $300 \mathrm{ml}$ were concentrated to a final volume of $3 \mathrm{ml}$ for both controls and for UV light-treated samples. The concentrate was immediately fixed in $3.5 \%$ electron microscopy-grade glutaraldehyde and stored at $4^{\circ} \mathrm{C}$ until examination by electron microscopy.

Suspended particles in concentrates were harvested directly by ultracentrifugation in a Beckman airfuge (Beckman Coulter, Fullerton, CA, USA) at $100000 \times g$ for $40 \mathrm{~min}$ onto carbon stabilised formvar-coated 200mesh copper grids. These were rinsed once in $0.02 \mu \mathrm{m}$ filtered Milli-Q water to remove salts and stained with $4 \%$ w/v $\mathrm{NH}_{4} \mathrm{MO}_{4}$ for $30 \mathrm{~s}$. Grids were air dried and observed using a JEOL 1010 electron microscope at $80 \mathrm{kV}$ accelerating voltage and $100000 \times$ magnification.

Effects of viruses produced by decaying Lyngbya majuscula on healthy cyanobacteria. Seawater was collected from an area of the Amity Banks bloom
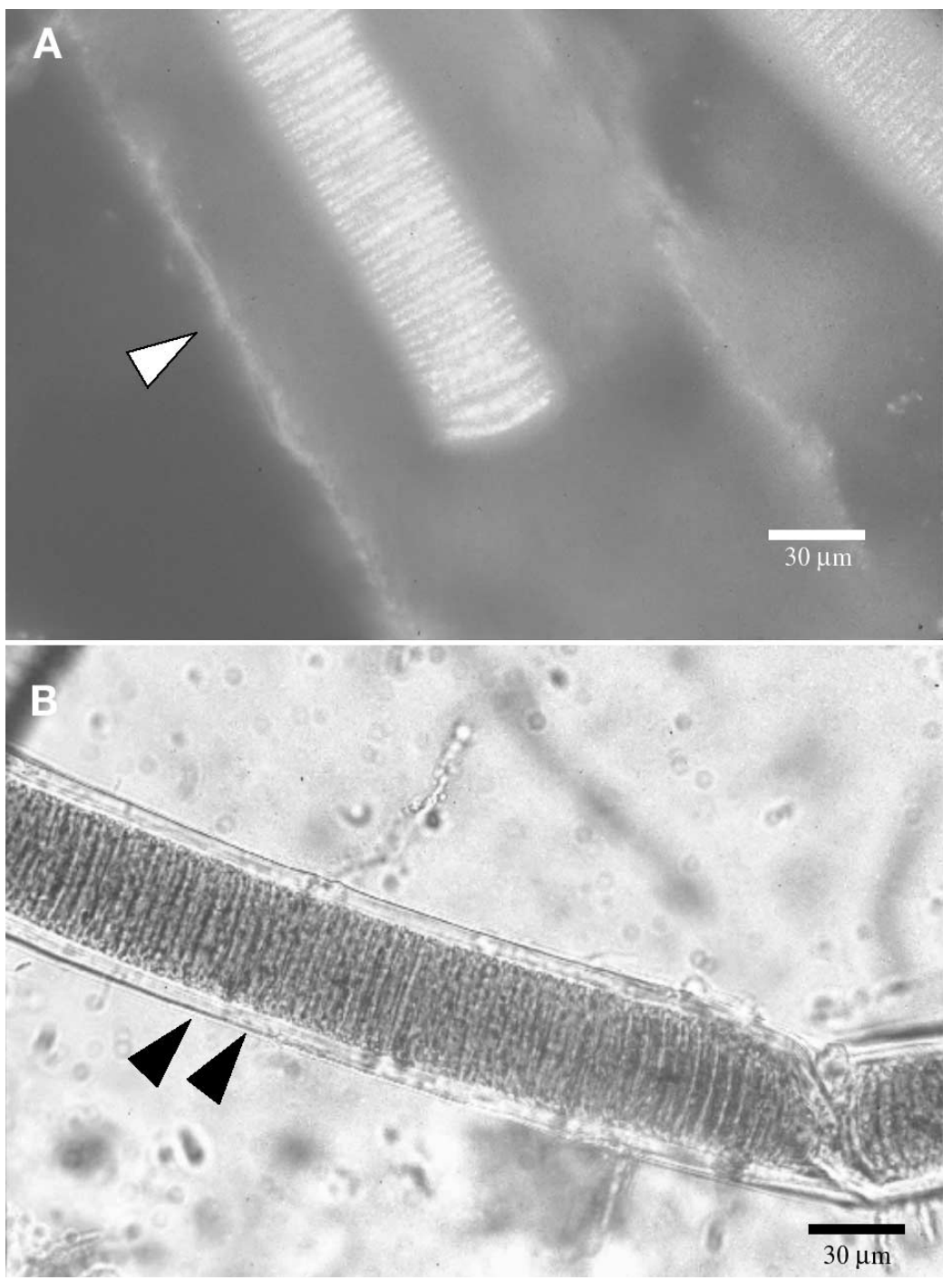

Fig. 2. Lyngbya majuscula (A) stained with SYBR Green I under epifluoresence microscopy and (B) under bright field microscopy. Arrowheads indicate sheath that is covered in heterotrophic bacteria

site (Fig. 1, Point B) that displayed

symptoms of bloom decay using sterile opaque 11 polypropylene containers. Air-filled bottles were submerged to a depth of $3 \mathrm{~m}$ and opened near mats of decomposing Lyngbya majuscula, then capped underwater, before being transported to the Moreton Bay Research Station.

Viruses were concentrated in several steps: (1) seawater collected around the Amity Banks bloom was prefiltered through a $0.7 \mu \mathrm{m}$ Whatman $\mathrm{GF} / \mathrm{F}$ filter to remove filaments of Lyngbya majuscula and large phytoplankton; (2) samples were then filtered through a $0.22 \mu \mathrm{m}$ Durapore low-protein binding filter (Millipore Corporation, Bedford, MA, USA) to remove bacteria; and (3) filtrate was concentrated using a Vivaflow 200 tangential-flow ultrafilter (Vivascience,
Hannover, Germany) driven by a peristaltic pump. Approximately 31 of Amity Banks seawater were concentrated to a final volume of $6 \mathrm{ml}$. Concentrates were observed under epilfuoresence microscopy using protocols of Noble \& Fuhrman (1998) as previously described.

Small sections ( 1 ml volume) of Lyngbya majuscula displaying no symptoms of decay were collected at a site approximately $2 \mathrm{~km}$ from decomposing cyanobacterial mats (Fig. 1, Point C) and were measured volumetrically as described above. L. majuscula sections were extruded into six $50 \mathrm{ml}$ polypropylene tissue culture flasks containing $50 \mathrm{ml}$ seawater from Amity Banks. Three flasks were inoculated with virus concentrates ( $2 \mathrm{ml}$ in each flask) while nothing was added 


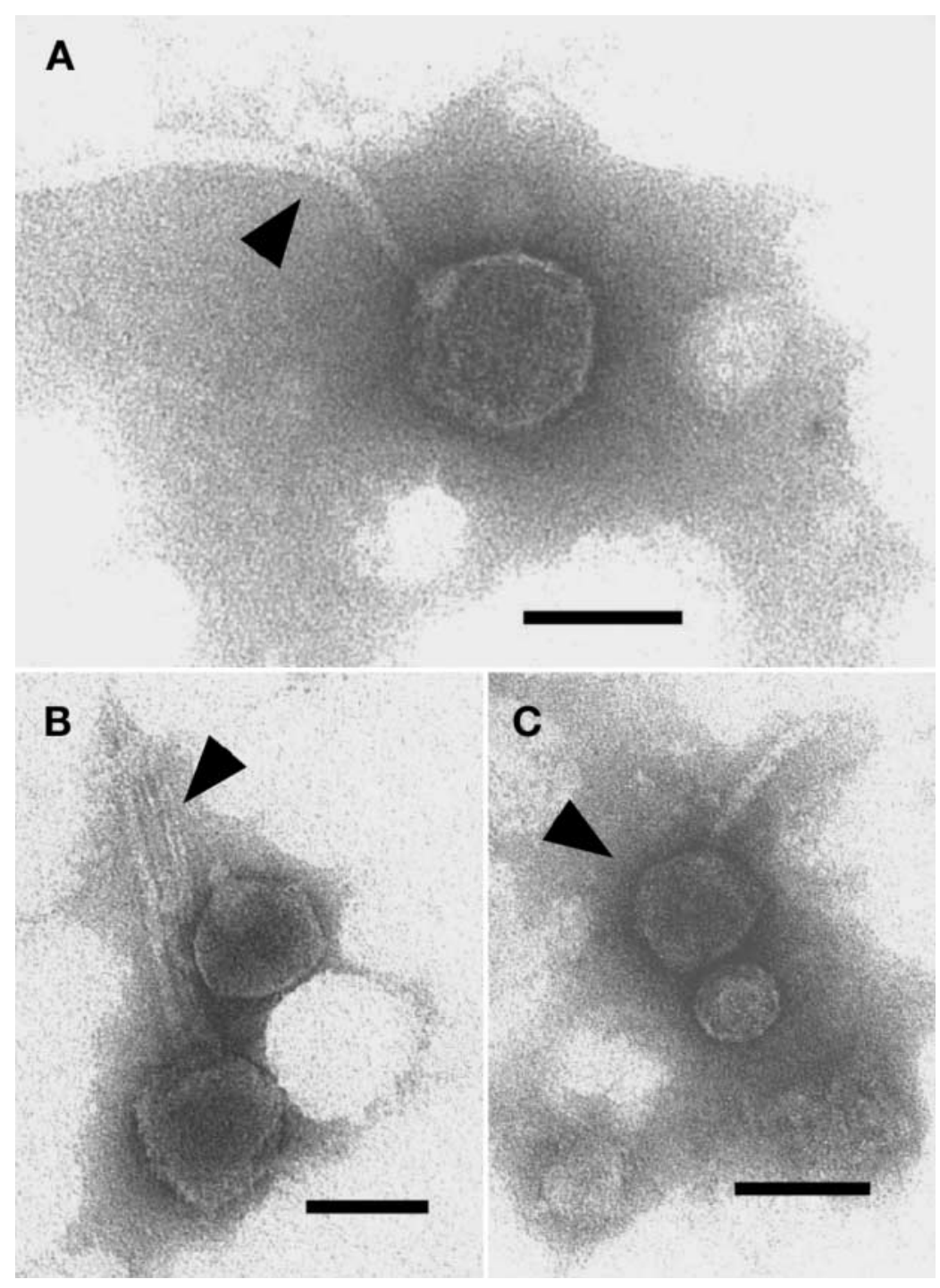

Fig. 3. (A) Electron micrograph of negatively stained phage particles from lysate of Lyngbya majuscula from Deception Bay. The long tail that appears to be flexible (arrowhead). (B) On the left is an intact particle, while on the right the tail of the particle has been broken off (arrowhead). (C) Electron micrograph of negatively stained virus-like particles from Amity Banks seawater concentrates. On the top is a virus-like particle morphologically similar to the cyanobacterial lysate (arrowhead) while below is an icosohedral virus-like particle. Scale bars $=50 \mathrm{~nm}$ maximum minus initial fluorescence) were measured. Rapid-light (photosynthesis - irradiance) curves were generated at ambient light (which was approximately $1000 \mu \mathrm{mol}$ quanta $\mathrm{m}^{-2}$ $\mathrm{s}^{-2}$ each day sampled) at random positions on cyanobacterial filaments. Three replicate measurements of fluorescence and photosynthesis were generated on L. majuscula from each flask at 1, 3 and $5 \mathrm{~d}$ after virus addition.

\section{RESULTS}

\section{Virus morphology}

Lyngbya majuscula collected was not colonised by heterotrophic bacteria. Blotted-dry filaments of decaying $L$. majuscula were devoid of associated bacteria, protists and metazoa.

VLP were observed in the lysate of UV-light-treated and -untreated Lyngbya majuscula from Deception Bay (Fig. 3a,b). VLP were predominantly binal with isomorphic heads 40 to $50 \mathrm{~nm}$ in diameter and tails 80 to $120 \mathrm{~nm}$ in length. Tails appeared bent or broken off in several VLP, indicating that they may have been flexible (Suttle 2000). On the basis of their morphology, the VLP belong to the family Siphonoviridae and genus Cyanostylovirus according to descriptions in Suttle (2000). Control lysate contained visibly fewer VLP than UV-treated samples; however, reliable enumeration of both treatments was not possible due to the low number of VLP per grid division, which seldom exceeded 30 . to the remaining 3 flasks (controls). Flasks were incubated in outdoor flow-through aquaria at $25^{\circ} \mathrm{C}$ and subjected to ambient light (typical maximum intensity of 800 to $1700 \mu \mathrm{mol}$ quanta $\mathrm{m}^{-2} \mathrm{~s}^{-1}$ ).

Photosynthesis and fluorescence of Lyngbya majuscula were measured using a pulse-amplitude modulated fluorometer (Walz Mess- and Regeltechnik, Bremen, Germany) (White \& Critchley 1999). Flasks were dark adapted for $15 \mathrm{~min}$, before initial fluorescence $\left(F_{\mathrm{o}}\right)$ and photochemical efficiency $\left(F_{\mathrm{v}} / F_{\mathrm{m}}\right.$, where $F_{\mathrm{m}}$ is the maximum excitable fluorescence and $F_{\mathrm{v}}$ is the

\section{Effects of elevated virus abundance on Lyngbya majuscula}

Viral concentrates added to Lyngbya majuscula contained no bacteria and approximately $2.3 \times 10^{10}$ VLP $\mathrm{ml}^{-1}$, while unconcentrated seawater contained approximately $7.2 \times 10^{6} \pm 4.8 \times 10^{5} \mathrm{VLP} \mathrm{ml}^{-1}$ and the abundance of bacteria at the site of collection was $3.6 \times 10^{5}$ $\pm 1.7 \times 10^{4}$ cells $\mathrm{ml}^{-1}$. It is estimated that addition of virus concentrate elevated virus abundance in the flasks by $25 \%$ above ambient levels. 

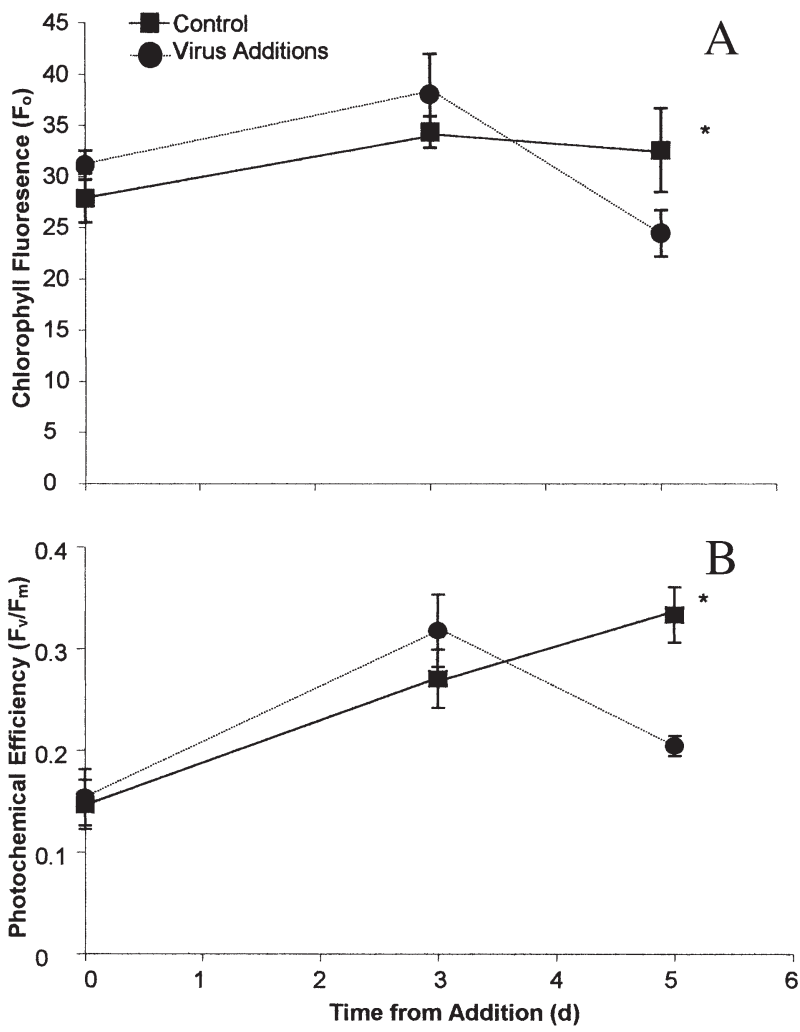

Fig. 4. Effect of virus concentrates on the state of PSII as measured by $(\mathrm{A})$ chlorophyll fluoresence $\left(F_{\mathrm{o}}\right.$ : initial fluorescence) and (B) photochemical efficiency $\left(F_{\mathrm{v}} / F_{\mathrm{m}}\right.$, where $F_{\mathrm{m}}$ is the maximum excitable fluorescence and $F_{v}$ is the maximum minus initial fluorescence). ${ }^{*}$ Significant differences at $\mathrm{p}<0.05$

Viral concentrate additions affected Lyngbya majuscula photosynthesis and the state of PSII, which indicates virus infection (Suttle et al 1990, Balanchandran et al. 1997). Evidence of viral infection was decreased maximum photosynthetic rate and photoinhibition of $L$. majuscula in virus additions after $5 \mathrm{~d}$ (Fig. 4); increased $F_{\mathrm{o}}$ after $3 \mathrm{~d}$ and then subsequent decrease after $5 \mathrm{~d} ;$ and decreased $F_{\mathrm{v}} / F_{\mathrm{m}}$ after $5 \mathrm{~d}$ (Fig. 5). The first indication of virus infection and onset of cell lysis was an increase in dark-adapted in vivo fluorescence after $3 \mathrm{~d}$ (concomitant with the release of red pigments into the culture flasks in virus additions, which was most likely phycoerythrin from lysed cells), followed by a decrease in $F_{\mathrm{o}}$ after cell lysis at $5 \mathrm{~d}$. This phenomena is due to the breakdown of the electron transport chain between PSII and PSI, which results in photochemical quenching of excess energy through fluorescence. After destabilisation of PSII-dependant protein turnover and degradation of photosynthetic membranes, $F_{\mathrm{o}}$ decreases as chlorophyll a degrades (Balachandran et al. 1997). Concomitant with the decline in $F_{\mathrm{o}}$ at $5 \mathrm{~d}$, photochemical efficiency was reduced, indicating reduced light use by damaged or degraded photosynthetic tissues.

\section{DISCUSSION}

Viruses have been implicated for some time as agents of bloom decline of freshwater cyanobacteria (reviewed in Martin \& Benson 1988) and eukaryotic phytoplankton (Bratbak et al. 1990, Nagasaki et al 1994). However, the role of viruses in bloom decline of macroscopic cyanobacterial species has not been previously investigated.

Cyanostylovirus observed in the lysate of Lyngbya majuscula are morphologically similar to cyanophages isolated from several freshwater cyanobacterial genera including Synechococcus elongatus (S-2L, SM-2), Microcystis aeruginosa (S-1) and LPP (Lyngbya, Phormidium and Plectonema) group cyanobacteria (LPP-1, LPP-2, LPP-3A) (reviewed in Martin \& Benson 1988) (Table 1). The tail structure of the $L$. majuscula virus is substantially shorter than the temperate cyanophage of Phormidium persicinum (Ohki \& Fujita 1996), another marine filamentous cyanobacteria with a Cyanostylovirus cyanophage.

The infection in Lyngbya majuscula may be by either lytic or temperate cyanophages. VLP were observed in greatest abundance after UV light treatment of $L$. majuscula. It is therefore proposed that the virus parti-

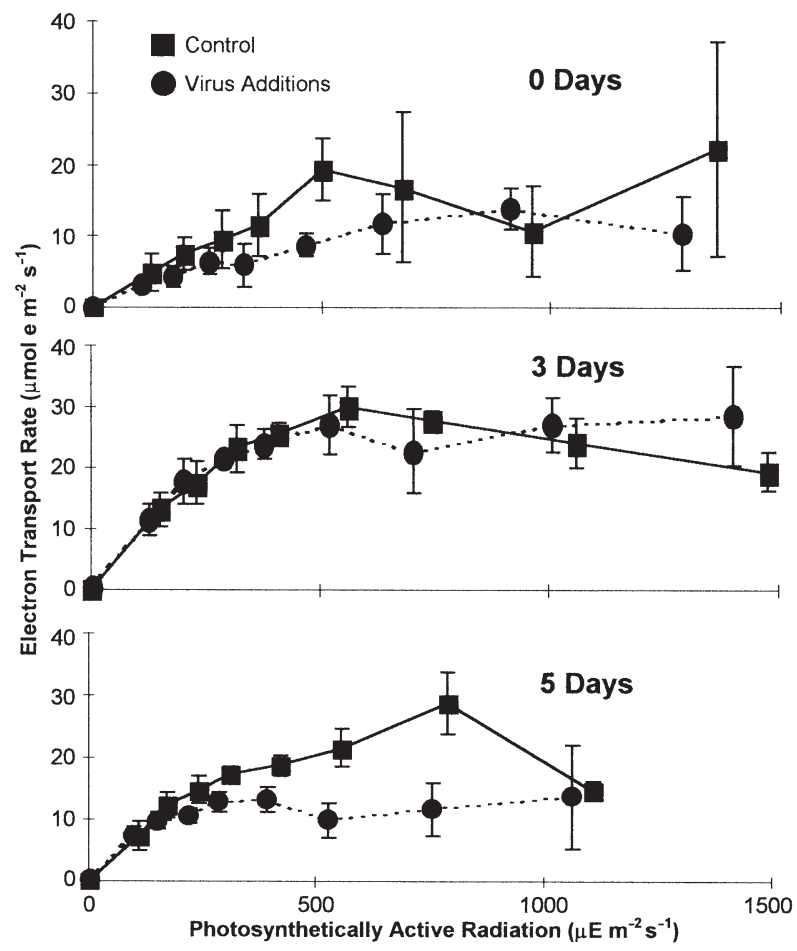

Fig. 5. Changes in photosynthesis of Lyngbya majuscula in the presence of elevated virus abundances as measured by pulse-amplitude modulated fluoresence. Data points are the mean of 3 measurements made at random points on filaments. Error bars indicate SD from means 
Table 1. Virus-like particles observed in Lyngbya majuscula lysate compared with other isolated cyanophages. diam.: diameter

\begin{tabular}{|c|c|c|c|c|}
\hline $\begin{array}{l}\text { Cyano- } \\
\text { phage }\end{array}$ & Host & $\begin{array}{l}\text { Capsid diam. } \\
\text { (nm) }\end{array}$ & Tail morphology & Source \\
\hline & Lyngbya majuscula & 50 to 60 & Contractile, 80 to $120 \mathrm{~nm}$ long & Present study \\
\hline S-1 & Microcystis aeruginosa & 50 & Noncontractile, $140 \mathrm{~nm}$ long & (Adolph \& Haselkorn 1973) \\
\hline S-2L & Synechococcus sp. & 56 & Noncontractile, $120 \mathrm{~nm}$ long & (Khudyakov 1977) \\
\hline SM-2 & Synechococcus elongatus & 50 to 55 & Noncontractile, 130 to $140 \mathrm{~nm}$ long & (Fox et al. 1976) \\
\hline LPP-1 & Lyngbya, Phormidium and Plectonema & 60 & Contractile, short & (Safferman \& Morris 1963) \\
\hline \multirow[t]{2}{*}{ LPP-2 } & Lyngbya, Phormidium and Plectonema & 60 & Contractile, short & (Safferman et al. 1969) \\
\hline & Phormidium persicinum & 40 & Noncontractile, $300 \mathrm{~nm}$ & (Ohki \& Fujita 1996) \\
\hline
\end{tabular}

cles observed were primarily temperate and induced by the UV light treatment; however, lytic cyanophage infection cannot be discounted as a possible cause of cyanobacterial disease since some VLP were produced in non-UV controls.

The presence of lytic virus particles around decomposing mats of the cyanobacterium can be inferred by comparing the photosynthetic response of non-decaying cyanobacteria after $3 \mathrm{~d}$ with cyanobacteria in the presence of virus populations augmented with lysate of decaying Lyngbya majuscula. High molecular weight concentrates (which are rich in viruses with capsids $>2 \mathrm{~nm}$ ) of seawater surrounding decaying $L$. majuscula reduced photosynthetic rate and caused photoinhibition in healthy L. majuscula after $5 \mathrm{~d}$ incubation. The maximum electron transport rate of virusenriched cyanobacterium was approximately $70 \%$ lower than that of L. majuscula with no viral addition (Fig. 5). This is similar to reduced rates reported for other cyanobacteria and microalgae in the presence of virus concentrates (Suttle et al. 1991, Suttle 1992).

The possible existence of temperate cyanophages of Lyngbya majuscula may help explain differences in toxicity previously noted within this species (Orjala et al. 1995). Cyanophages have been shown to be important in genetic exchange among prokaryotes (Jiang \& Paul 1998), and genes responsible for toxin production may be a result of the inclusion of a temperate cyanophage genome in host DNA, as is observed in other bacteria (Waldor \& Mekalanos 1996). Additionally, it has been shown that toxic strains of Microcystis aeruginosa have temperate inducible phage, while non-toxic strains do not have temperate cyanophage (Vance 1977).

This study emphasises the need for further research into the consequences of potential cyanophageinduced collapse of Lyngbya majuscula blooms. In particular, the understanding of L. majuscula host-cell resistance dynamics and decay rates of cyanophage under bloom conditions is essential to the complete understanding of the role of cyanophage in bloom dinsintegration.
Acknowledgements. We are grateful to A. Watkinson, C. Roelfsema, G. Bratbak, the Marine Botany Group at the University of Queensland, J. Fuhrman, J. Rose, D. Ginsburg, P. Countway, M. Schwalbach, S. Lambert, D. Caron and 4 anonymous reviewers for valuable comments on the manuscript. This research was funded through the Department of Botany at the University of Queensland and ARC Grant No. C19937066 awarded to W.C.D.

\section{LITERATURE CITED}

Adolph KW, Haselkorn R (1973) Isolation and characterisation of a virus infecting a blue-green alga of the genus Synechococcus. Virology 54:230

Balachandran S, Hurry VM, Kelley SE, Osmond CB, Robinson SA, Rohozinski J, Seaton GGR, Sims DA (1997) Concepts of plant biotic stress. Some insights into the stress physiology of virus-infected plants, from the perspective of photosynthesis. Physiol Plant 100:203-213

Bergh O, Borsheim KY, Bratbak G, Heldal M (1989) High abundance of viruses found in aquatic environments. Nature 340:467-468

Bratbak G, Heldal M, Norland S, Thingstad TF (1990) Viruses as partners in spring bloom microbial trophodynamics. Appl Environ Microbiol 56:1400-1405

Dennison WC, Abal EG (1999) Moreton Bay study: a scientific basis for the Healthy Waterways Campaign. South East Queensland Regional Water Quality Management strategy, Brisbane

Dennison WC, O'Neil JM, Duffy EJ, Oliver PE, Shaw GR (1999) Blooms of the cyanobacteria Lyngbya majuscula in coastal waters of Queensland, Australia. Bull Inst Oceanogr Monaco 19:501-506

Fox JA, Booth SJ, Martin EL (1976) Cyanophage SM-2: a new blue-green algal virus. Virology 73:557-560

Fuhrman JA (1999) Marine viruses and their biogeochemical and ecological effects. Nature 399:541-548

Jiang SC, Paul JH (1998) Gene transfer by transduction in the marine environment. Appl Environ Microbiol 64: 2780-2787

Khudyakov IY (1977) Characteristics of a new cyanophage S2L lysing the unicellular cyanobacterium belonging to the Synechococcus genus. Mikrobiologiya 46:547-553

Martin E, Benson R (1988) Phages of cyanobacteria. In: Calendar R (ed) The bacteriophages. Plenum Press, New York, p 607-645

Nagasaki K, Ando N, Itakura S, Imai I, Ishida Y (1994) Viral mortality in the final stage of Heterosigma akashiwo (Raphidophyceae) red tide. J Plankton Res 16:1595-1599 Noble RT, Fuhrman JA (1998) Use of SYBR Green I for rapid 
epifluorescence counts of marine viruses and bacteria. Aquat Microb Ecol 14:113-118

Ohki K (1999) A possible role of temperate phage in the regulation of Trichodesmium biomass. Bull Inst Oceanogr Monaco 19:287-292

Ohki K, Fujita Y (1996) Occurrence of a temperate cyanophage lysogenizing the marine cyanophyte Phormidium persicinum. J Phycol 32:365-370

Orjala J, Nagle DG, Hsu VL, Gerwick WH (1995) Antillatoxin: an exceptionally ichthyotoxic cyclic lipopeptide from the tropical cyanobacterium Lyngbya majuscula. J Am Chem Soc 117:8281-8282

Proctor LM, Fuhrman JA, Ledbetter MB (1988) Marine bacteriophages and bacterial mortality. EOS 69:1111-1112

Safferman RS, Morris ME (1963) Algal virus: isolation. Science 140:679-680

Safferman RS, Schneider LR, Steere RL, Morris ME, Diener TO (1969) Phycovirus SM-1: a virus infecting unicellular blue-green algae. Virology 37:386

Suttle CA (1992) Inhibition of photosynthesis in phytoplankton by the submicron size fraction concentrated from seawater. Mar Ecol Prog Ser 87:105-112

Suttle CA (2000) Cyanophages and their role in the ecology of cyanobacteria. In: Whitton A, Potts M (eds) The ecology of

Editorial responsibility: Fereidoun Rassoulzadegan,

Villefranche-sur-Mer, France cyanobacteria. Kluwer Academic Publishers, Amsterdam, p 563-589

Suttle CA, Chan AM (1993) Marine cyanophages infecting oceanic and coastal strains of Synechococcus: abundance, morphology, cross-infectivity and growth characteristics. Mar Ecol Prog Ser 92:99-109

Suttle CA, Chan AM, Cottrell MT (1990) Infection of phytoplankton by viruses and reduction of primary production. Nature 347:467-469

Suttle CA, Chan AM, Cottrell MT (1991) Use of ultrafiltration to isolate viruses from seawater which are pathogens of marine phytoplankton. Appl Environ Microbiol 57: $721-726$

Vance BD (1977) Prophage induction in toxic Microcystis acruginosa NRC-1. J Phycol (Suppl) 13:70

Waldor MK, Mekalanos JJ (1996) Lysogenic conversion by a filamentous phage encoding cholera toxin. Science 272: 1910-1914

White AJ, Critchley C (1999) Rapid light curves: a new fluorescence method to assess the state of the photosynthetic apparatus. Photosynthesis Res 59:63-72

Wilson WH, Mann NH (1997) Lysogenic and lytic viral production in marine microbial communities. Aquat Microb Ecol 13:95-100

Submitted: May 2, 2001; Accepted: June 27, 2001

Proofs received from author(s): September 20, 2001 